\title{
EFEKTIVITAS PENGGUNAAN MODEL KOOPERATIF TIPE JIGSAW DAN STAD TERHADAP HASIL BELAJAR IPS SISWA KELAS V SD IMBAS GUGUS DIPONEGORO KABUPATEN BLORA
}

\author{
Galih Gusti Prihatanti, Henny Dewi Koeswanti \\ Surel: 292013206@ student.uksw.edu
}

\begin{abstract}
This study aims to try to overcome the problem of IPS learning by applying cooperative learning model of jigsaw and STAD type and to know the effectiveness of cooperative learning model of jigsaw and STAD type. The subjects of the study were $V$ grade students from SDN Sumberjo 01, SDN Sumberjo 02, and SDN Pilang 01. The results showed that the average learning outcomes of the experimental class were 86.54, while the mean of the students' learning achievement was 69, 21. The result of t-test of the research was obtained by significance value of 2 tailed at 0.000, where $0.000<0,05$, meaning that there is effectivity of cooperative learning model type jigsaw and STAD to student learning result of IPS class $V$.
\end{abstract}

Keywords: IPS Learning Outcomes, Jigsaw, STAD

\begin{abstract}
ABSTRAK
Penelitian ini bertujuan untuk mencoba mengatasi permasalahan pembelajaran IPS dengan menerapkan model cooperative learning tipe Jigsaw dan STAD dan untuk mengetahui efektivitas model pembelajaran kooperatif tipe jigsaw dan STAD. Subjek penelitian yaitu siswa kelas V dari SDN Sumberjo 01, SDN Sumberjo 02, dan SDN Pilang 01. Hasil penelitian menunjukkan perolehan rata-rata hasil belajar siswa kelas eksperimen yaitu sebesar 86,54, sedangkan rata-rata hasil belajar siswa kelas kontrol sebesar 69,21. Hasil Uji t penelitian diperoleh nilai signifikansi 2 sebesar 0,000, dimana $0,000<0,05$, yang artinya terdapat efektivitas penggunaan model cooperative learning tipe Jigsaw dan STAD terhadap hasil belajar IPS siswa kelas V.
\end{abstract}

Kata Kunci : Hasil Belajar IPS, Jigsaw, STAD

\section{PENDAHULUAN}

Ilmu pengetahuan sosial di SD merupakan suatu cabang ilmu yang berpusat pada pengetahuan tentang lingkungan sekitar dalam konteks lingkungan sosial serta lingkungan alam fisik. Segala sesuatu yang berkaitan dengan lingkungan kehidupan sosial dan lingkungan alam fisik mencakup cabang ilmu geografi, sejarah, ekonomi, dan sosiologi, dikaji dalam satu kesatuan ilmu yang lebih sederhana dalam IPS SD.

Berdasarkan KTSP tahun 2006, disebutkan tujuan pembelajaran IPS SD/MI sebagai berikut : mengenal konsep-konsep yang berkaitan dengan dengan kehidupan

Jurusan PGSD FKIP Universitas Kristen Satya Wacana 
masyarakat dan lingkungannya, memiliki kemampuan dasar berpikir logis, kritis, rasa ingin tahu inkuiri, memecahkan masalah dan ketrampilan kehidupan sosial, memiliki komitmen dan kesadaran terhadap nilai-nialai sosial kemanusiaan, memiliki kemampuan dasar berkomunikasi, bekerjasama, dan berkompetisi dalam masyarakat yang majemuk di tingkal lokal, nasional, dan global.

Untuk mewujudkan tujuan pembelajaran IPS di atas, maka seorang guru harus membuat rancangan pembelajaran yang kreatif sehingga siswa akan tertarik mengikuti pembelajaran dan akan merasa senang dengan kegiatan pembelajaran yang mereka lakukan. Tantangan tersendiri sebagai seorang pengajar untuk membuat rancangan pembelajaran IPS yang menarik, mengingat materi IPS SD tidaklah sedikit. Disini profesionalitas pengajar diuji, apakah pengajar mampu untuk membuat pembelajaran yang menyenangkan atau tidak. Rancangan pembelajaran IPS yang menyenangkan dapat dilihat dari strategi, pendekatan, model, dan metode apa yang digunakan oleh pengejar.

Ilmu pengetahuan sosial berhubungan dengan cara memahami lingkungan kehidupan manusia. Pada dasarnya IPS merupakan sekumpulan cabang dari berbagai macam ilmu, tidak heran jika dalam IPS terdapat banyak sekali materi yang disajikan. Berbagai macam materi yang dituangkan dalam IPS harus disampaikan kepada siswa dengan cara yang benar, terlebih untuk siswa SD. Karena banyaknya materi yang disajikan dalam IPS, sebaiknya dalam penyampaiannya digunakan pembelajaran yang kreatif, inovatif, serta melibatkan siswa secara aktif dalam pembelajaran. Namun terkadang pembelajaran hanya disampaikan dengan menekankan aspek kognitif saja, kurang melibatkan siswa sehingga siswa kurang mandiri dalam belajar, bahkan cenderung pasif, siswa di dalam kelas hanya diam mendengarkan dan mencatat (Etin Solihatin, 2011:2). Penyampaian pembelajaran yang hanya menekankan aspek kognitif saja, biasanya disampaikan menggunakan metode ceramah. Rooijakkers (2010:4) mengemukakan bahwa siswa yang mengikuti pembelajaran dengan metode ceramah hanya dapat mengingat $40 \%$ (empat puluh persen) dari informasi terpenting yang disampaikan oleh guru. Padahal jika menelisik dari tahapan berpikir menurut Piaget (Trianto, 2010:71), siswa SD masih berada pada tahapan berpikir operasional konkret, itu artinya siswa SD perlu mendapat pengarahan yang sifatnya nyata, bukan menggunakan metode ceramah dalam pembelajaran. Oleh karena itu perlu adanya implementasi pembelajaran yang 
sesuai dengan perkembangan peserta didik. Pembelajaran yang kreatif dan melibatkan siswa secara aktif adalah pembelajaran yang tepat diaplikasikan guna menyampaikan materi pelajaran kepada peserta didik pada jenjang Sekolah Dasar.

Pembelajaran secara kreatif dengan melibatkan siswa secara aktif, dapat dipadukan dengan berbagai model pembelajaran, salah satunya adalah model pembelajaran kooperatif. Model pembelajaran kooperatif atau sering disebut cooperative learning merupakan salah satu model pembelajaran yang berpusat pada siswa (student center). Pembelajaran kooperatif merujuk pada berbagai macam metode pengajaran dimana para siswa bekerja dalam kelompok-kelompok kecil untuk saling membantu satu sama lain dalam mempelajari materi pelajaran (Slavin, 2015:4). Untuk menyelesaikan masalah yang sering muncul dalam pembelajaran IPS, maka digunakanlah dua model pembelajaran kooperatif yakni Jigsaw dan STAD.

Jigsaw merupakan metode pembelajaran dimana siswa dibagi kedalam kelompok beranggotakan 4-6 orang secara beragam dimana setiap siswa bergantung kepada siswa lain dalam kelompoknya untuk dapat memberikan informasi yang diperlukan (Isjoni, 2007: 55). Rusman (2013:218) mengemukakan langkahlangkah model jigsaw sebagai berikut
(1) siswa dikelompokan dengan anggota kurang lebih 4 orang (2) tiap orang dalam tim diberi materi dan tugas yang berbeda (3) anggota dari tim yang berbeda dengan penugasan yang sama membentuk kelompok baru (kelompok ahli) (4) setelah kelompok ahli berdiskusi, tiap anggota kembali ke kelompok asal dan menjelaskan tentang subbab yang mereka kuasai (5) tiap tim ahli mempresentasikan hasil diskusi (6) pembahasan (7) penutup. Sedangkan Student Team Achievement Divisions atau STAD adalah model pembelajaran yang menekankan adanya aktivitas dan interaksi antar siswa untuk saling memotivasi dan saling membantu dalam menguasai materi pelajaran untuk mencapai prestasi yang maksimal (Isjoni, 2009:51). Langkahlangkah STAD menurut Slavin (2015: 147-159) sebagai berikut (1) persiapan, pada tahap persiapan ini ada beberapa langkah yang harus dilakukan antara lain membagi siswa ke dalam tim atau kelompok, menentukan skor awal dan membangun tim (2) pembukaan, tiap pelajaran STAD dimulai dengan presentasi pelajaran yang akan dipelajari di dalam kelas. Pada tahap pembukaan perlu menyampaikan kepada siswa tentang materi yang akan dipelajari dan mengapa materi tersebut penting untuk dipelajari (3) belajar tim, selama masa belajar tim, tugas para anggota tim adalah 
menguasai materi yang disampaikan guru dalam kelas dan membantu teman satu timnya agar menguasai materi tersebut. Para siswa mempunyai lembar kegiatan dan lembar jawaban yang dapat digunakan untuk melatih kemampuan selama proses pembelajaran dan bisa digunakan untuk menilai dirinya sendiri dan teman satu timnya (4) tes, kuis atau tes pada penilaian STAD dilakukan secara individual. Siswa bisa mengumpulkan hasil tesnya kepada guru, kemudian guru membagikan lembar jawaban kuis secara acak untuk dinilai siswa bersama-sama (5) menghitung skor individual dan tim, setelah didapatkan nilai dari kuis yang dikerjakan siswa, langkah selanjutnya adalah menghitung skor individu siswa. Skor individu dihitung berdasarkan kemajuan nilai siswa dari nilai kuis sebelumnya. Setelah semua skor kemajuan individu siswa sudah didapat, maka guru menghitung ratarata skor tim dengan cara menjumlahkan semua skor individu anggota tim kemudian dirata-rata. Jika skor tim sudah didapat, maka tim bisa mendapat penghargaan sesuai predikat yang didapat timnya.

Sesuai dengan pembahasan di atas, maka penelitian ini dilakukan dengan tujuan untuk mengetahui efektivitas penggunaan model pembelajaran kooperatif tipe jigsaw dan STAD terhadap hasil belajar IPS siswa kelas V SD Imbas gugus
Diponegoro kabupaten Blora dalam mata pelajaran IPS semester II tahun ajaran 2016/2017.

\section{METODE PENELITIAN}

Penelitian ini disusun menggunakan jenis penelitian semu (quasi experimental research). Jenis penelitian ini bisa mengontrol sumber-sumber non validitas (Hamid Darmadi, 2011:201). Desain penelitian yang digunakan dalam penelitian ini adalah Posttest-Only Control Design. Sampel penelitian ini diambil menggunakan teknik Simple Random Sampling yang artinya pengambilan sampel dilakukan secara acak tanpa memperhatikan strata dalam populasi tersebut.

Tabel 1. Rancangan Penelitian

\begin{tabular}{|c|c|c|c|}
\hline Sampel & Sebelum & Perlakuan & Sesudah \\
\hline $\begin{array}{c}\text { Kelas } \\
\text { eksperi } \\
\text { men }\end{array}$ & $\begin{array}{c}\text { Tanpa } \\
\text { pretes, } \\
\text { samplin } \\
\text { g secara } \\
\text { random }\end{array}$ & $\begin{array}{c}\text { Pembelajaran } \\
\text { menggunakan } \\
\text { jigsaw }\end{array}$ & $\begin{array}{c}\text { Hasil } \\
\text { belajar } \\
\text { berdasar } \\
\text { kan } \\
\text { posttes }\end{array}$ \\
\hline $\begin{array}{c}\text { Kelas } \\
\text { kontrol }\end{array}$ & $\begin{array}{c}\text { Tanpa } \\
\text { pretes, } \\
\text { samplin } \\
\text { g secara } \\
\text { random }\end{array}$ & $\begin{array}{c}\text { Pembelajaran } \\
\text { menggunakan } \\
\text { STAD }\end{array}$ & $\begin{array}{c}\text { Hasil } \\
\text { belajar } \\
\text { berdasar } \\
\text { kan } \\
\text { posttes }\end{array}$ \\
\hline
\end{tabular}

Dalam penelitian ini, populasi yang akan digunakan adalah siswa kelas V dari SDN Sumberjo 01, siswa kelas V SDN Sumberjo 02, dan siswa kelas V SDN Pilang 01. Teknik pengumpulan data yang digunakan adalah tes hasil belajar yang dilaksanakan setelah adanya penerapan model pembelajaran 
kooperatif tipe Jigsaw dan STAD pada kompetensi dasar menghargai jasa dan peranan tokoh perjuangan dalam mempersiapkan kemerdekaan Indonesia.

Instrumen pengumpulan data dalam penelitian ini menggunakan butir-butir soal tes hasil belajar IPS siswa pada kompetensi dasar menghargai jasa dan peranan tokoh perjuangan dalam mempersiapkan kemerdekaan Indonesia dalam bentuk tes obyektif berupa soal pilihan ganda yang terdiri dari 30 soal yang sebelumnya telah diuji validitas dan reliabilitasnya sebagai berikut.

Berdasarkan hasil uji reliabilitas instrument, maka diperoleh hasil sebagai berikut:

Tabel 2. Hasil Uji Reliabilitas

Cronbach's $\quad \mathrm{N}$ of Items

\begin{tabular}{cc} 
Alpha & \\
\hline 809 & 50 \\
\hline
\end{tabular}

Suatu instrumen penlitian dikatan reliabel jika nilai koefisien reliabelnya lebih besar dari (>) 0,6 (Syofian Siregar, 2012:175). Hasil uji reliablitas menggunakan Cronbach's Alpha, didapat nilai sebesar 0,809. Karena nilai yang didapat lebih dari 0,6 maka dapat diambil kesimpulan bahwa soal yang diujikan terbukti reliabel.

\section{HASIL DAN PEMBAHASAN}

Analisis deskriptif penelitian ini diolah menggunakan SPSS 16.
Dalam analisis deskriptif penelitian diperlihatkan data penelitian berupa nilai mean, maximum, minimum, dan standar deviasi. Hasil analisis statistiknya dapat dilihat pada tabel di bawah ini.

\section{Tabel 2. Deskriptif Statistik Hasil \\ Belajar Siswa Kelas Eksperimen dan Kelas Kontrol}

\begin{tabular}{cccccc|} 
& N & Mean & $\begin{array}{c}\text { Std. } \\
\text { Deviatio } \\
\mathrm{n}\end{array}$ & Min. Max. \\
\hline EKSPERIMEN & 24 & 86.54 & 8.209 & 73 & 100 \\
\hline KONTROL & 19 & 69.21 & 7.906 & 57 & 80
\end{tabular}

Dari tabel 2 diketahui bahwa kelas eksperimen yakni kelas V SDN 1 Sumberjo jumlah data (N) sebanyak 24 siswa dengan rata-rata hasil belajar sebesar 86,54 dengan skor hasil belajar minimal sebesar 73, skor maksimal sebesar 100, dan standar deviasinya yaitu 8,20. Sedangkan untuk hasil belajar siswa SDN 2 Sumberjo sebagai kelas kontrol dengan jumlah data (N) sebanyak 19 siswa mempunyai skor rata-rata hasil belajar sebesar 69,21 dengan skor hasil belajar minimal sebesar 57, skor maksimal sebesar 80 dan standar deviasinya yaitu 7,90. Dapat disimpulkan bahwa rata-rata hasil belajar siswa kelas eksperimen lebih baik jika dibandingkan dengan ratarata hasil belajar siswa kelas kontrol.

\section{Uji Normalitas}

Uji normalitas dilakukan untuk mengetahui apakah data berdistribusi normal atau tidak. Uji 
normalitas dilakukan menggunakan Uji Kolmogrov Smirnov pada SPSS 16. Jika nilai signifikansi $<0,05$ dapat diartikan bahwa data berdistribusi tidak normal, sebaliknya jika nilai signifikansi >0,05 maka data berdistribusi normal.

Tabel 3. Hasil Uji Normalitas Hasil Belajar Siswa Kelas Eksperimen dan Kelas Kontrol

\begin{tabular}{|c|c|c|c|}
\hline & EKSPERIMEN & KONTROL \\
\hline \multicolumn{2}{|l|}{$\mathrm{N}$} & 24 & 19 \\
\hline \multirow{3}{*}{$\begin{array}{l}\text { Normal } \\
\text { Parameters }^{\mathrm{a}}\end{array}$} & Mean & 86.54 & \multirow{3}{*}{$\begin{array}{l}69.21 \\
7.906\end{array}$} \\
\hline & Std. & & \\
\hline & $\begin{array}{l}\text { Deviati } \\
\text { on }\end{array}$ & 8.209 & \\
\hline \multirow[t]{3}{*}{$\begin{array}{l}\text { Most Extreme } \\
\text { Differences }\end{array}$} & $\begin{array}{l}\text { Absolu } \\
\text { te }\end{array}$ & .125 & .154 \\
\hline & $\begin{array}{l}\text { Positiv } \\
\text { e }\end{array}$ & .125 & .136 \\
\hline & $\begin{array}{l}\text { Negati } \\
\text { ve }\end{array}$ & -.122 & -.154 \\
\hline \multicolumn{2}{|c|}{ Kolmogorov-Smirnov Z } & .614 & .669 \\
\hline \multicolumn{2}{|c|}{ Asymp. Sig. (2-tailed) } & .846 & .762 \\
\hline
\end{tabular}

Hasil uji normalitas menunjukkan nilai signifikansi (2tailed) kelas eksperimen sebesar 0,846 dan kelas kontrol mempunyai nilai signifikan sebesar 0,762 . Suatu data dikatakan berdistribusi normal apabila memiliki nilai signifikansi lebih besar dari 0,05. Nilai signifikansi kelas eksperimen $0,846>0,05, \quad$ sedangkan nilai signifikansi kelas kontrol 0,762> 0,05 . Maka dapat disimpulkan bahwa populasi data hasil belajar siswa kelas eksperimen dan kelas kontrol berdistribusi normal.

\section{Uji Homogenitas}

Uji homogenitas dalam penelitian ini diukur menggunakan Levene Test pada SPSS 16, dengan tujuan untuk mengetahui apakah kedua variabel mempunyai varian yang sama atau tidak. Jika nilai signifikansi $<0,05$ dapat diartikan bahwa data tidak memiliki varian yang sama, sebaliknya jika nilai signifikansi >0,05 maka data memiliki varian yang sama atau homogeny. Hasil uji homogenitas penelitian ini dapat dilihat pada tabel berikut:

Tabel 4. Hasil Uji Homogenitas Hasil Belajar Siswa Kelas Eksperimen dan Kelas Kontrol

\begin{tabular}{cccc}
$\begin{array}{c}\text { Levene } \\
\text { Statistic }\end{array}$ & df1 & df2 & Sig. \\
\hline .018 & 1 & 41 & .894 \\
\hline
\end{tabular}

Diketahui pada tabel hasil uji homogenitas didapat nilai signifikansi sebesar 0,894. Suatu data dikatakan homogen apabila dalam pengolahan uji homogenitas nilai yang diperoleh lebih besar dari 0,05. Hasil uji homogenitas penelitian adalah sebesar $0,894>0,05$. Dapat disimpulkan bahwa antara kelas eksperimen dan kelas kontrol memiliki varian yang sama atau homogen.

\section{Uji T-test}

Uji t dilakukan untuk menguji hipotesis penelitian berupa pengaruh variabel bebas terhadap variabel terikat. Pengujian ini dilakukan dengan uji Independent sample T-test 
dengan taraf signifikansi sebesar 5\%. Jika nilai signifikansi >0,05 makan $\mathrm{H}_{0}$ diterima, sebaliknya jika nilai signifikansi $<0,05$ maka $\mathrm{H}_{0}$ ditolak.
Jika $\mathrm{H}_{0}$ ditolak, maka $\mathrm{H}_{1}$ diterima, menandakan bahwa adanya perbedaan yang signifikan antara kedua metode.

Tabel 5. Hasil Uji Independent Sample T-Test Kelas Eksperimen dan Kelas Kontrol

\begin{tabular}{|c|c|c|c|c|c|c|c|c|c|c|}
\hline & & $\begin{array}{r}\text { Lev } \\
\text { Tes } \\
\text { Equa } \\
\text { Vari }\end{array}$ & $\begin{array}{l}\text { e's } \\
\text { or } \\
y \text { of } \\
\text { ces }\end{array}$ & & & & t for Equalit & of Means & & \\
\hline & & \multirow[t]{2}{*}{$\mathrm{F}$} & \multirow[t]{2}{*}{$\begin{array}{l}\mathrm{Si} \\
\mathrm{g} .\end{array}$} & \multirow[t]{2}{*}{$\mathrm{t}$} & \multirow[t]{2}{*}{ df } & \multirow[t]{2}{*}{$\begin{array}{l}\text { Sig. (2- } \\
\text { tailed) }\end{array}$} & \multirow[t]{2}{*}{$\begin{array}{c}\text { Mean } \\
\text { Difference }\end{array}$} & \multirow[t]{2}{*}{$\begin{array}{l}\text { Std. Error } \\
\text { Difference }\end{array}$} & \multicolumn{2}{|c|}{$\begin{array}{l}\text { 95\% Confidence } \\
\text { Interval of the } \\
\text { Difference }\end{array}$} \\
\hline & & & & & & & & & Lower & Upper \\
\hline \multirow{2}{*}{$\begin{array}{c}\text { HASIL } \\
\text { BELAJAR }\end{array}$} & $\begin{array}{c}\text { Equal } \\
\text { variances } \\
\text { assumed }\end{array}$ & .018 & $\begin{array}{c}.89 \\
4\end{array}$ & 6.987 & 41 & .000 & 17.331 & 2.480 & 12.322 & 22.341 \\
\hline & $\begin{array}{c}\text { Equal } \\
\text { variances } \\
\text { not } \\
\text { assumed }\end{array}$ & & & 7.018 & 39.385 & .000 & 17.331 & 2.469 & 12.338 & 22.324 \\
\hline
\end{tabular}

Berdasarkan hasil uji Independent Sample T-Tes pada kolom signifikansi (2 tailed) bagian Equal Variances Assumed, diperoleh nilai sebesar 0,000 . Dengan perolehan nilai tersebut, dapat diketahui bahwa hasil uji $t$ pada penelitian ini mempunyai nilai $0,000<0,05$, maka dapat disimpulkan bahwa $\mathrm{H}_{0}$ ditolak dan $\mathrm{H}_{1}$ diterima.

Hipotesis dalam penelitian ini dirumuskan sebagai berikut :

$\mathrm{H}_{0} \quad$ : tidak ada pengaruh yang signifikan antara metode jigsaw dan STAD terhadap hasil belajar IPS siswa.

$\mathrm{H}_{1} \quad$ : ada pengaruh yang signifikan antara metode jigsaw dan STAD terhadap hasil belajar IPS siswa.

Dari hasil uji hipotesis, dapat diketahui bahwa terdapat perbedaan pengaruh antara metode jigsaw dan STAD (Student Team Achievement Divisions) terhadap hasil belajar IPS siswa kelas V SD imbas gugus Diponegoro Kecamatan Randublatung, Kabupaten Blora tahun ajaran 2016/2017.

Subjek penelitian sebagai kelas eksperimen yaitu kelas V SDN 1 Sumberjo diberikan perlakuan berupa pembelajaran menggunakan metode jigsaw dengan 24 siswa. Sedangkan kelas kontrol adalah kelas V SDN 2 Sumberjo dengan siswa sejumlah 19 siswa diberikan pengajaran menggunakan metode STAD. Pengumpulan data hasil belajar siswa dilakukan menggunakan instrument tes pilihan ganda dengan jumlah 30 butir soal, yang diperoleh melalui post test setelah diberikan 
pembelajaran kepada kedua subjek penelitian.

Berdasarkan hasil penelitian yang telah dilakukan, diketahui bahwa kelas eksperimen memperoleh rata-rata hasil belajar sebesar 86,54 dengan skor hasil belajar minimal sebesar 73, skor maksimal sebesar 100, dan standar deviasinya yaitu 8,20 . Jumlah frekuensi data kelas eksperimen sebanyak 24 siswa. Sedangkan untuk hasil belajar siswa kelas kontrol dengan jumlah data sebanyak 19 siswa mempunyai skor rata-rata hasil belajar sebesar 69,21 dengan skor hasil belajar minimal sebesar 57, skor maksimal sebesar 80 dan standar deviasinya yaitu 7,90 .

Dengan menggunakan Uji Independent Sample T-Tes pada hasil belajar kelas eksperimen dan kelas kontrol, diperoleh hasil nilai sig. (2tailed) signifikan sebesar 0,00 dengan probabilitas signifikansi $0,00<0,05$, maka dapat disimpulkan bahwa $\mathrm{H}_{0}$ ditolak dan $\mathrm{H}_{1}$ diterima. Dengan demikian berdasarkan hasil pengujian menunjukkan adanya perbedaan pengaruh yang signifikan antara hasil belajar IPS siswa yang diberikan perlakuan dengan metode jigsaw dengan hasil belajar siswa yang diberikan perlakuan menggunakan metode STAD.

Kelas

eksperimen

menunjukkan perolehan rata-rata hasil belajar sebesar 86,54 , sedangkan ratarata hasil belajar kelas control sebesar 69,21. Berdasarkan nilai rata-rata tersebut, dapat diketahui bahwa hasil belajar siswa kelas eksperimen yakni siswa yang diberikan perlakuan berupa pembelajaran dengan menggunakan metode jigsaw lebih baik jika dibandingkan dengan nilai rata-rata siswa kelas kontrol yang diberikan pembelajaran dengan menggunakan metode STAD pada mata pelajaran IPS dengan Kompetensi Dasar menghargai jasa dan peranan tokoh perjuangan dalam mempersiapkan kemerdekaan Indonesia.

Hasil penelitian ini sejalan dengan hasil penelitian yang telah dilakukan oleh Tanti Listiani pada tahun 2013 mahasiswa program studi S1 Pendidikan Matematika, Universitas Kristen Satya Wacana dalam skripsinya yang berjudul "Efektivitas model pembelajaran kooperatif tipe STAD (Student Teams Achievement Divisions) dengan model pembelajaran kooperatif tipe jigsaw terhadap hasil belajar matematika siswa kelas VIII SMP Negeri 7 Salatiga pada materi lingkaran". Dalam penelitian ini menyimpulkan bahwa metode jigsaw jika dibandingkan STAD lebih berpengaruh signifikan terhadap hasil belajar matematika siswa dengan nilai t hitung sebesar 3,336 dan probabilitas signifikansi (2-tailed) sebesar $0,002<0,05$. Terbukti juga dari perolehan rata-rata siswa kelas eksperimen yang diberi perlakuan menggunakan metode jigsaw sebesar 
85,19 sedangkan rata-rata hasil belajar siswa kelas kontrol yang diberi perlakuan menggunakan metode STAD sebesar 74,81.

\section{SIMPULAN}

Berdasarkan hasil analisis data dan pembahasan maka dapat disimpulkan bahwa ada perbedaan efektivitas penggunaan model pembelajaran kooperatif tipe jigsaw dan STAD (Student Team Achievement Divisions) terhadap hasil belajar IPS siswa kelas V SD imbas gugus Diponegoro Kecamatan Randublatung Kabupaten Blora tahun ajaran 2016/2017, pada Kompetensi Dasar menghargai jasa dan peranan tokoh perjuangan dalam mempersiapkan kemerdekaan Indonesia. Berdasarkan perolehan rata-rata hasil belajar siswa SDN 1 Sumberjo sebagai kelas eksperimen yaitu sebesar 86,54, sedangkan ratarata hasil belajar siswa SDN 2 Sumberjo sebagai kelas kontrol sebesar 69,21. Dari kedua nilai ratarata tersebut dapat diketahui bahwa hasil belajar siswa yang menggunakan metode jigsaw lebih baik dibandingkan hasil belajar siswa dengan menggunakan metode STAD karena dalam proses pembelajaran, jigsaw menuntut siswa bertanggungjawab terhadap pembagian materi yang didapatnya sehingga semua siswa benar-benar mengerti materi yang sedang dipelajari.
DAFTAR RUJUKAN

Darmadi, H. 2011. Metode Penelitian Pendidikan. Bandung: Alfabeta.

Isjoni. 2007. Cooperative Learning. Bandung: Alfabeta.

Isjoni. 2009. Pembelajaran Kooperatif Meningkatkan

Kecerdasan Komunikasi antar Peserta Didik. Yogyakarta: Pustaka Pelajar.

Rooijakkers. 2010. Mengajar dengan Sukses. Jakarta: Grasindo.

Rusman. 2013. Model-Model Pembelajaran

Mengembangakan

Profesionalisme Guru. Jakarta:

Raja Grafindo Persada.

Siregar, S. (2012). Statistika Deskriptif untuk Penelitian: Dilengkapi Perhitungan Manual dan Aplikasi SPSS Versi 17. Jakarta: Rajawali Pers.

Slavin, Robert. 2015. Cooperative Learning Teori, Riset dan Praktik. Bandung: Penerbit Nusa Media.

Solihatin, E., \& Raharjo. 2011. Cooperative Learning Analisis Pembelajaran IPS. Jakarta: Bumi Aksara.

Trianto. 2010. Model Pembelajaran Terpadu Konsep, Strategi, dan Implementasinya dalam Kurikulum Tingkat Satuan Pendidikan (KTSP). Jakarta: Bumi Aksara. 